\title{
Low Cost Approaches to Improve Quality of Life \& Access to Healthcare in Brazilian Favelas
}

\section{Jeanniton (Lindsey Jeanniton)}

Health Administration \& Human Resources,

\section{Original Articles}

$4^{\text {th }}$ Floor McGurrin Hall, Scranton, PA 18510-4699

\section{E-mail address:}

ljeanniton4@gmail.com

\section{Reprint address:}

Health Administration \&

Human Resources

$4^{\text {th }}$ Floor McGurrin Hall

Scranton, PA 18510-4699

Suource: Clinical Social Work and Health Intervention

Volume: 7

Issue: 4

Pages: $46-54$

\section{Reviewers:}

Dr. Jirina Kafkova, Ph.D.

Nairobi, St. Bakitha Clinic, Kenya

e-mail: jirinka.lala@gmail.com

Dr. Alexander Wolf

Association of palliative and hospice care, Kiev, Ukraine

e-mail: doroha@inbox.ru

\section{Key words:}

Extreme poverty, Brazil, Healthcare, Education, Malnutrition.

\section{Publisher:}

International Society of Applied Preventive Medicine i-gap

CSWHI 2016; 7(4): 46 - 54; 10.22359/cswhi_7_4_07 @ 2016 Clinical Social Work and Health Intervention

\section{Abstract:}

Throughout Brazil, there is a wide gap between the rich and the poor in respect to their resources. There are about 12 million people in Brazil who live in extreme poverty within shantytowns, known as favelas. ${ }^{17}$ These people lack basic public services, such as education, space, and most importantly healthcare. These people lack basic public services such as education, space, and most importantly healthcare. As a result, 
there are high incidences of malnutrition, diarrhea, skin diseases, and many other diseases. ${ }^{15}$ In addition, living in such conditions can negatively impact one's health. Six factors that can greatly improve and maintain healthy living in the favelas: cleanliness; nutrition; doctor visits; herbal remedies (tomar cha); sympathetic magic; spirituality. In order to better the quality and access of healthcare for the people living in the favelas, it is necessary to use low cost strategies. Using other countries' strategies and implementations can help Brazil improve healthcare in the favelas.

\section{Introduction}

The extreme differences in socioeconomic status among people in Brazil contribute to the health conditions. ${ }^{14}$ Poor living conditions in Brazilian favelas, also known as shantytowns or slums, present a major challenge; increases in health problems, diseases, and mortalities. For example, the crowded housing increases the spread of tropical diseases; a major problem Brazil must address. To improve healthcare in the favelas, it is important for healthcare managers and leaders to look at the costs, quality and access. There have been many models and programs used in other countries with similar conditions like the favelas to improve healthcare. Three low cost strategies proposed to improve both the quality and access are 1) Information and Communications Technology, 2) Transportation Program, 3) Target Program that Benefits the Poor.

\section{Problems and Challenges}

Favelas are units of irregular self-constructed housing that are occupied illegally. These housing units are usually located on the hillsides; some overlook urban cities and rich areas of Brazil. ${ }^{5}$ Poor living conditions are the root of many problems Brazilians living in the favelas face. Some of these conditions include the crowding of buildings; unsanitary conditions; poor nutrition; pollution. As shown in Figure 1, health and education are the two topics which matter the most to people in Brazil. ${ }^{3}$ However, as illustrated below the favelas suffer in regards to health, quality of education, and safety. Specifically in Rio de Janeiro, residents living in the favelas live about 13 years less than people born in the wealthy areas. Child mortality rates are also five times higher. ${ }^{8}$

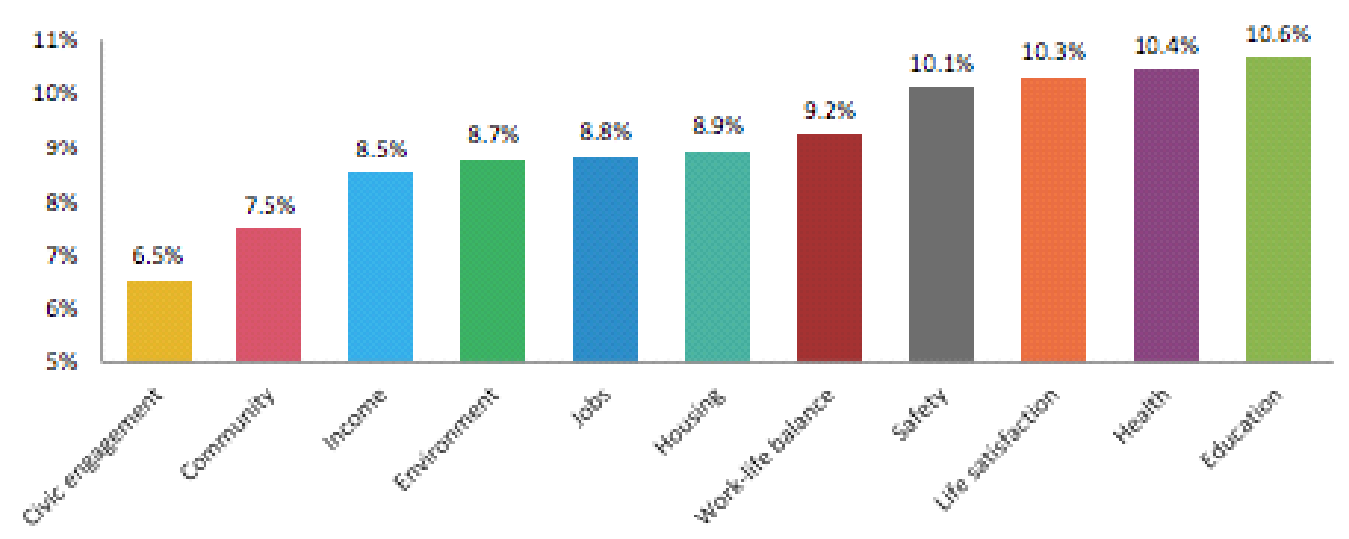

Figure 1 Topics that Matter the Most to People in Brazil. ${ }^{13}$ 
One of the barriers people living in the favelas face is the lack of education. Brazil recognizes the importance of education, and provides free public education at all levels. However, due to the socioeconomic gap present in Brazil, there is a major academic difference among the schools. Due to the lack of resources and adequate amenities, the children in less affluent areas are unable to receive a proper education and suffer for this later in life. In addition, there are children who are unable to attend school because they are malnourished. Other families need their children to start working in order to contribute to the household income. There are many laborers as young as 10 years old who decide to forego a public education to earn money to help their family. ${ }^{4}$

Due to the overcrowding of buildings and narrow roads, most of the favelas lack effective sewage systems and have limited access to portable water and waste management systems. ${ }^{12}$ Most diseases such as Cholera, Malaria, and Dengue Fever are all linked to deficient waste and water systems. Poor sewage diseases, major health problems, and mortality rates.

\section{Neglected Tropical Diseases}

People living in favelas face an increasing number of cases of, and deaths by, Neglected Tropical Diseases (NTD). It is crucial that Brazil address these diseases by educating the people, and implementing low cost strategies to fix healthcare in these areas. According to the World Health Organization, several of the world's major NTDs occur in Brazil. However, most of these NTDs are found in the favelas because of the overcrowded housing, inadequate supply of water, and poor sewage system and waste management. Table 1 illustrates the types of NTDs, along with the number of reported cases and number of deaths from 1998 through 2007. ${ }^{9}$ Malaria and Dengue Fever show a high number of reported cases, and Tuberculosis is the cause of a large number of deaths. Although this is data from 2007, the number of reported cases of and deaths from NTDs has increased and the new Zika virus is a major health concern in Brazil. ${ }^{9}$

\begin{tabular}{|c|c|c|c|}
\hline Nezlected Tropical Diseases & Toeal number of reported cases & Number of deaths & Case fanality rate \\
\hline Visceral Leishmanizsis & 33,787 & 1,598 & $4.73 \%$ \\
\hline Tegumentary Leixhmaniasis (a) & 268.866 & $616 * * *$ & 0225 \\
\hline Malaria & $4,791,853$ & 960 & $002 \%$ \\
\hline Dengue fever & $3,317,662$ & 463 & 00138 \\
\hline Tubercukasis & 631.887 & 22,937 & $3.3 \%$ \\
\hline Chagas' Disease* & 444 & 14 & $3 \%$ \\
\hline Schislosamiasis & $1,031,838$ & 4,539 & $0.43 \%$ \\
\hline Leprosy $* *(\mathrm{a})$ & 405.860 & 11,794 & $29 \%$ \\
\hline
\end{tabular}

Source: Health Serveillance Service of the Ministry of Health of Brazil and DNTASUS. Death by (a) were not considered bexic cause of dead. * Data available cely for Acute Chagas' Disease from 2005 through $2008 ; \cdots$ Data available from 2004 to 2006 . $\cdots$ Dats available from 2001 to 2007.

Table 1 Estimated Number of Neglected Tropical Diseases in Brazil (from 1998 through 2007) ${ }^{9}$

systems and waste management systems result in increases of mosquitos. ${ }^{12}$ Infestations of mosquitos carry viruses which are then transmitted to a large number of people living in these favelas. Poor living conditions in the favelas of Brazil are linked to the rise in cases and transmission of neglected tropical
Parasitic, bacterial, fungal, ectoparasitic, or viral agents can cause these NTDs. The majority of these NTDs are transmitted by mosquitos, which is a big problem in the favelas. The favelas create a perfect environment for disease causing mosquitos to breed. ${ }^{15}$ The WHO has separated these 
NTDs into 3categories based on emergence, control, and drug availability. Table 2 divides the NTDs into the three categories. ${ }^{9}$ Understanding how NTDs are separated into 3 categories is important. In order for Brazil to prevent and lower the cases of NTDs, implementation of low cost strategies to help improve the quality of life and access to healthcare must move forward. Following models from countries with similar conditions and diseases as Brazil is a step in the right direction to fix this problem. Although most of these NTDs are transmitted in poor living conditions in the favelas, Figure 2 shows the distribution of the NTDs throughout Brazil. similar conditions to the Brazilian favelas have implemented models focusing on low cost and improvement of healthcare. In healthcare, cost, access, and quality are all connected. Even though many of the health problems come from poor living conditions, and most of the living conditions cannot be fixed, there are ways of improving healthcare. Implementing programs and using models from other countries with similar conditions can help improve the healthcare in the favelas. It is proposed that three low cost strategies can promote better quality of life and access to care in Brazilian favelas. 3 low cost strategies are:

\begin{tabular}{lll}
\hline $\begin{array}{l}\text { Category } 1 . \\
\begin{array}{l}\text { Emerging and } \\
\text { uncontrolled disease }\end{array}\end{array}$ & $\begin{array}{l}\text { Category 2. } \\
\text { Control strategy available } \\
\text { Disease burden persists }\end{array}$ & $\begin{array}{l}\text { Category 3. } \\
\text { Control strategy effective } \\
\text { Disease burden falling } \\
\text { Elimination planned }\end{array}$ \\
\hline Leishmaniasis & Malaria & Chagas' Discase \\
African Trypanosomiasis & Schistosomiasis & Leprosy \\
Dengue fever & Tuberculosis & Lymphatic filariasis \\
& & Onchocerciasis \\
\hline
\end{tabular}

Table 2 WHO categorization of NTDs based on emergence, control and drug availability ${ }^{9}$

\section{Low Cost Strategies}

In order to fix a problem, it must first be identified by analyzing all the contributing factors. Many poor environments with

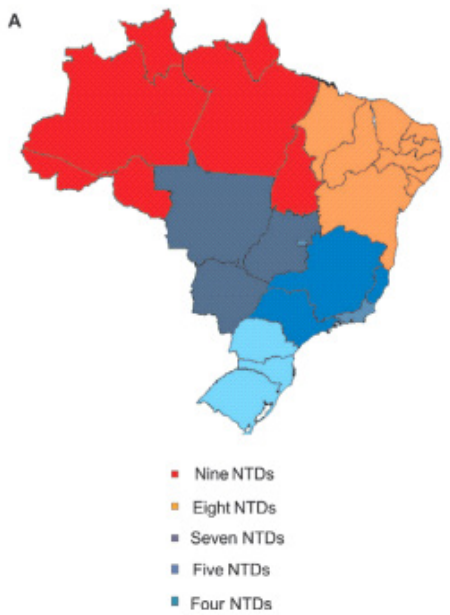

- Information and Communications Technology

- Transportation Program

- Target Program that Benefits the Poor

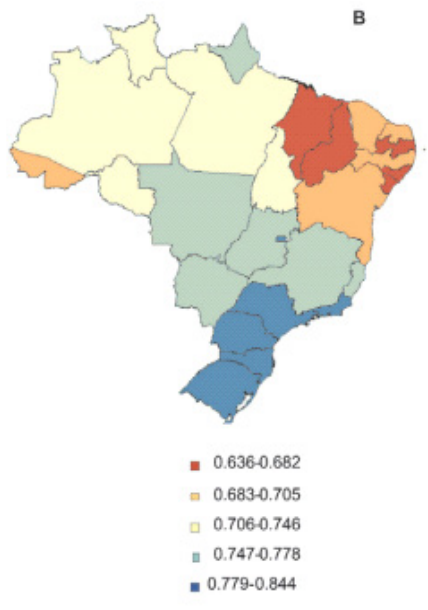

Figure 2 (A) Distribution of the main Neglected Tropical Diseases in Brazil from the Health Surveillance Service (Ministry of Health) ${ }^{9}$ 


\section{Information and Communications Technology}

Technology can have a tremendously positive effect on healthcare. Implementers are searching for innovative approaches to eliminate geographic and financial barriers to health. Several countries are using a variety of information and communications technology tools to help improve quality and access of healthcare with low cost. There are many purposes of technology-enabled programs, some of which are illustrated in Figure 3, and each program serves a certain purpose in the use of technology. ${ }^{11}$
Implementing technology-enabled programs in Brazil is a low cost strategy that will be useful in the favelas. Technology-enabled programs overcome distances between physicians and patients by replacing a traditional office with telemedicine. By facilitating greater communication with patients, technology-enabled programs provide health workers or programs, and patients with general health education outside of regular office locations and hours. Technology-enabled programs may additionally improve diagnosis and treatment, which will allow health workers to improve clinical performance during training or in the field, and will allow health workers to make better decisions and diagnosis. ${ }^{11}$

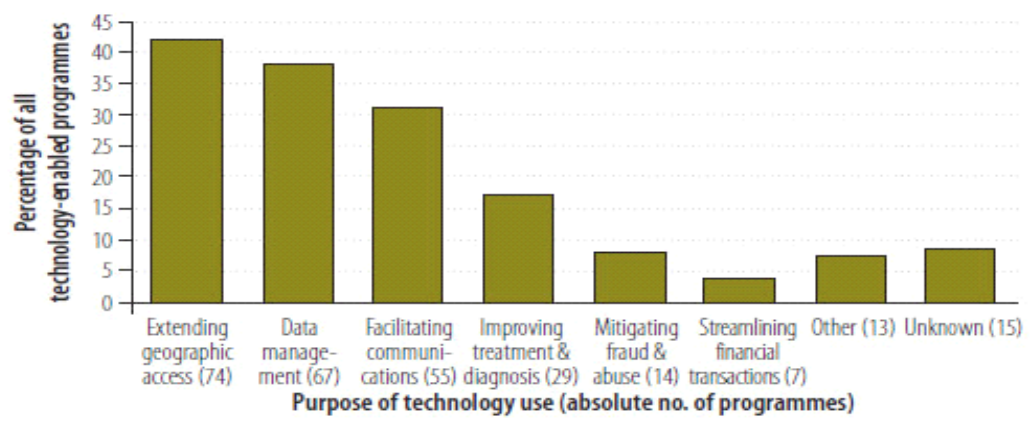

Note: Individual programmes can fall under multiple purposes; as such, percentages do not sum to 100 . Source: Center for Health Market Innovations.

Figure 3 Technology-Enabled Programs, by Purpose of Use of Technology"
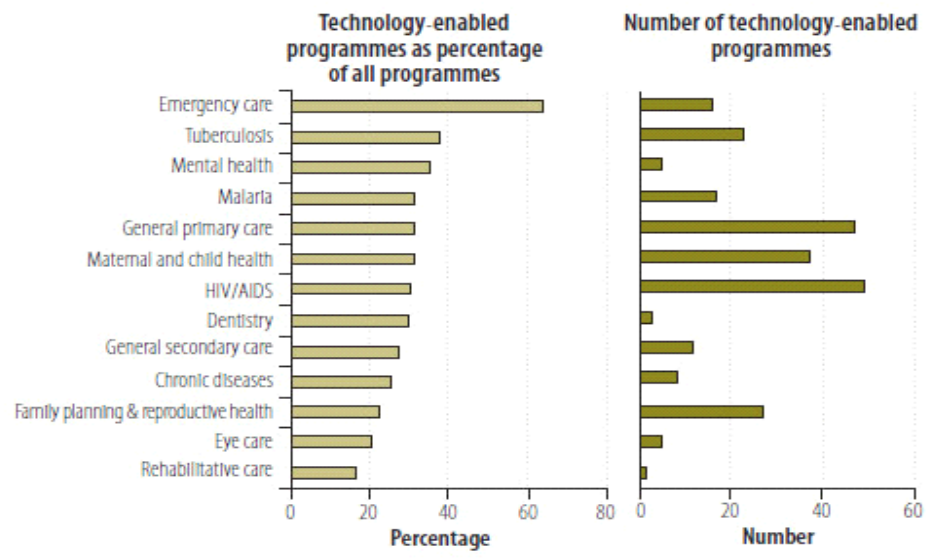

Source: Center for Health Market Innovations.

AIDS, acquired immunodeficiency syndrome; HIV, human immunodeficiency virus.

Figure 4 Technology-Enabled Programs, by Health Focus ${ }^{11}$ 
As stated previously, some of Brazil's NTDs that are increasing in cases and number of deaths are malaria and tuberculosis. HIV/AIDS is also a problem in Brazil, especially in the favelas. In 2013, there have been about 730,000 people living with HIV and 16,000 AIDS-related deaths. ${ }^{17}$ Figure 4 illustrates the number of technology enabled programs used to improve certain diseases and types of care. Implementing these programs will help improve the problems and health issues that occur in the favelas. That being said, many devices can be used to move the programs forward in the right direction. Table 3 illustrates how many devices such as phones and computers are used for technology-enabled programs. A large part of the population in the favelas uses mobile technology and computers. ${ }^{11}$
Phones serve many purposes besides communication. In fact, the Brazilian Government has invested heavily in mobile telephone networks and in broadband. In the favelas, "LAN houses" allow many people to access the internet and have become quite popular. UN Women, UNICEF and UN-Habitat launched an online website and smartphone app in 2013 to provide support services for women and girls and to report any violence, especially in the favelas. ${ }^{18}$ If Brazil took this initiative to improve safety, then implementing technology-enabled programs specifically for phones will improve the quality and access of healthcare at a low cost. A simple messaging system and data system that can be reviewed by Doctors could improve the healthcare in the favelas. Table 4 discusses the outcomes of mobile devices used in countries. The results provide Brazil with valuable data, and support the integration of mobile devices into everyday healthcare.

\begin{tabular}{lcc}
\hline Device & \multicolumn{2}{c}{ Programmes } \\
\cline { 2 - 3 } & No. & \% a \\
\hline Phone & 125 & 71 \\
Computer & 68 & 39 \\
Camera [video/photo] & 13 & 7 \\
PDAs/tablets & 11 & 6 \\
GPS & 9 & 5 \\
Remote diagnostic tool & 8 & 5 \\
Smartcard & 6 & 3 \\
Unique identification & 5 & 3 \\
Radio & 5 & 3 \\
Other & 14 & 8 \\
\hline
\end{tabular}

GPS, global positioning system; PDA, personal digital assistant.

a Represents the percentage among all technology-enabled programmes.

Source: Center for Health Market Innovations.

Table 3 Technology-Enabled Programs, by Type of Device ${ }^{11}$ 


\begin{tabular}{|c|c|c|}
\hline Country & $\begin{array}{c}\text { Indication / } \\
\text { Disease }\end{array}$ & Results \\
\hline United States & HIV & $\begin{array}{l}\text { "...high satisfaction with the messaging } \\
\text { system ... it helped with medication } \\
\text { adherence." } \\
\text { Participants reported missing one or } \\
\text { more doses on } 36 \% \text { of } 743 \text { queries. }\end{array}$ \\
\hline Tenerife & Diabetes & $\begin{array}{l}\text { Patients used system every } 2.0 \text { days } \\
\text { and doctors reviewed data every } 4.0 \\
\text { days Seventy five percent expressed a } \\
\text { preference for sending their data via } \\
\text { the mobile phone SMS }\end{array}$ \\
\hline South Africa & Tuberculosis & Adherence not measured \\
\hline South Africa & HIV & $\begin{array}{l}\text { Data published at the Civil } \\
\text { Engineering Department of The } \\
\text { University of Cape Town. }\end{array}$ \\
\hline
\end{tabular}

Table 4 Outcomes of Mobile ${ }^{6}$

\section{Transportation Program}

Transportation is a critical area in healthcare access, serving as a link between home and health facilities. ${ }^{1}$ Not many hospitals are located in the favelas, and transportation can be costly for many people in Brazil, especially the people living in favelas. Also, favelas are filled with narrow roads where travelling can be difficult. A perfect example of a transportation program that Brazil can implement is Riders for Health, an organization used by many countries in Africa. This organization makes sure that healthcare is more widely available for people. "Their mission is to make the 'last mile' is the most important mile in healthcare delivery: creating, showing and sharing the solutions for achieving truly equitable healthcare." ${ }^{14}$ Similar to Brazil's health issues such as malaria, tuberculosis, HIV/AIDS, Riders for Health serves a great purpose to prevent, educate, and treat people with these diseases in Africa. By managing motorcycles, ambulances, and other four-wheel vehicles, health workers are able to follow up with patients, conduct health education meetings, and create a link with primary health centers to improve patient samples, supplies and medicines. ${ }^{14}$ Riders for Health is a program Brazil can implement or use as a model to develop a transportation program reaching out to the people in the favelas.

\section{Target Program that Benefits the Poor}

To improve both quality and access to healthcare, specifically for poor and developing areas, a low cost strategy that targets vulnerable populations would be most effective. An example that Brazil can perhaps follow is Mexico's implementation of PROGRESSA. Mexico used this program as a strategy to decrease poverty while improving health and education.

PROGRESSA's role was "to lay the groundwork for a healthy, well-educated population who could successfully contribute to Mexico's economic development and break the intergenerational cycle of poverty." 
This program offered cash transfers to the poor in exchange for sending their children to school and regular attendance at health clinics and sessions that focuses on nutritional education. This program proved to be extremely successful and had positive outcomes in Mexico. ${ }^{10}$ For example, children involved with PROGRESSA had a 12 percent lower incidence of illness, households were consuming higher-quality foods, and there were an increased number of prenatal visits. ${ }^{10}$ Implementing a similar program like PROGRESSA that benefits and targets the poor in Brazil will certainly improve the quality of life of the people living in the favelas at a very low cost.

\section{Conclusion}

There are many ways to improve the health conditions in a certain area. Healthcare Managers and Professionals must identify the problems, and take the necessary actions and steps to solve them. Brazil's social gap between the rich and the poor will not change overnight. The problems and challenges of Brazilian favelas such as poor living conditions and Neglected Tropical Diseases increase the rate of disease transmission and the number of deaths among that population. By implementing low cost strategies it is possible to alleviate identified problems and therefore improve access to healthcare and people's quality of life. The three low cost strategies discussed, 1) Information and Communication Technology, 2) Transportation Program, and 3) Target Program that Benefits the Poor are just some approaches that are used by countries with living conditions and health problems similar to Brazil's favelas.

\section{References}

1. Atuoye, K.N., Dixon, J., Rishworth, A., Galaa, S.Z., Boamah, S. A., Luginaah, I. (2015). Can she make it? Transportation barriers to accessing maternal and child healthcare services in rural Ghana. BMC Health Services Research BMC Health Serv Res, 15(1). doi:10.1186/s12913-015-1005-y

2. BMC Health Services Research (Can she make it? Transportation barriers to accessing maternal and child healthcare services in rural Ghana) http://bmchealthservres. biomedcentral.com/articles/10.1186/ s12913-015-1005-y

3. Brazil (2015, October). Retrieved February 16, 2016, from http://www.oecdbetterlifeindex.org/countries/brazil/

4. Brazil (n.d.). Retrieved February 16, 2016 http://www.brazil.org.za/social-issues.html.

5. Global Footprints (n.d.) Favelas in Brazil. Retrieved from http://www.globalfootprints. org/issues/local/homeless/favelas.htm

6. Globalization and Health (2006). Retrieved January 6, 2016, fromhttp:/globalizationandhealth.biomedcentral.com/articles/ 10.1186/1744-8603-2-9

7. Unger, A., Riley, L. (2007). Slum Health: From Understanding to Action Plos Med PLoS Medicine. In Rio de Janeiro's favelas (2013, June 6) a new online tool tackles violence against women and girls. Retrieved February 16, 2016, from http:/www.unwomen.org/en/news/stories/2013/6/rio-dejaneiro-apps-to-end-violence-in-favelas

8. IRIN, UN-HABITAT (September, 2007). Rio: fighting for the favelas. Tomorrow's Crises Today: The humanitarian impact of urbanization. Retrieved from http://www. irinnews.org/pdf/in-depth/tomorrowscrisestoday-chapter6.pdf

9. Kawková, S., Bužgová, R. 2015: Aktivizace seniorů s demencí v pobytovém zařízení sociálních služeb a její vliv na kvalitu života. In: Rehabilitácia ISSN 0375-0922, Vol. 52, 2015, No 4, p. 249-256

10. Lindoso, J., Lindoso, A. (2009). Neglected tropical diseases in Brazil Revista Do Instituto De Medicina Tropical De São Paulo Rev. Inst. Med. Trop. S. Paulo, 247-253. 
11. Leigh Gantner (2007). Case Study \#5-1, "PROGRESA: An Integrated Approach to Poverty Alleviation in Mexico”. In: Per Pinstrup-Andersen and Fuzhi Cheng (editors), Food Policy for Developing Countries: Case Studies. 11pp.URL: http://cip.cornell. edu/dns.gfs/1200428168

12. Lewis, T., Synowiec, C., Lagomarsino, G., Schweitzer, J. (2012). E-health in low-and middle-income countries: Findings from the Center for Health Market Innovations. Bulletin of the World Health Organization Bull World Health Org, 332-340.

13. Logan, A. (2015). Fixing Favelas: Urban Housing Problems in Brazil. Retrieved February 16, 2016, from http://borgenproject. org/fixing-favelas-urban-housing-problems-brazil/
14. Welcome to Riders (n.d.). Retrieved January 6, 2016, from http://www.riders.org/ about-us.

15. Szwarcwald, C.L. (2000). Health conditions and residential concentration of poverty: A Study in Rio de Janeiro, Brazil. Journal of Epidemiology \& Community Health, 54(7), $530-536<$ jech $>$.

16. The Favelas of Brazil (n.d.). Retrieved February 16, 2016, from http://www.csus.edu/ writingcenter/corream/essay.html

17. UN Joint Program on HIV/AIDS (UNAIDS) The Gap Report 2014, available at: http://www.refworld.org/docid/53f1e1604. html [accessed 16 February 2016]

18. United, Favelas Would form Brazil's 5th Largest State (2013, February 23). Retrieved from http://www.rioonwatch.org/?p=6913 